\title{
Chemical compositions and volatile compounds of Sabah indigenous durian (Durio dulcis Becc.)
}

\author{
${ }^{1 *}$ Hasmadi, M, ${ }^{1}$ Nor Qhairul Izzreen, M.N., ${ }^{1}$ Mansoor, A.H., ${ }^{1}$ Jahurul, M.H.A. and \\ ${ }^{2}$ Zainol, M.K \\ ${ }^{1}$ Faculty of Food Science and Nutrition, Universiti Malaysia Sabah, 88400 Kota Kinabalu, Sabah, Malaysia \\ ${ }^{2}$ Faculty of Fisheries and Food Science, Universiti Malaysia Terengganu, 21030, Kuala Nerus, Terengganu
}

\begin{abstract}
Article history:
Received: 28 September 2020 Received in revised form: 16 November 2020

Accepted: 1 January 2021 Available Online: 18 April 2021
\end{abstract}

\section{Keywords:}

Durian,

Chemical compositions,

Fatty acid composition

DOI:

https://doi.org/10.26656/fr.2017.5(2).545

\begin{abstract}
The objective of this present work is to determine the chemical compositions and volatile compounds of Sabah indigenous durian (Durio dulcis Becc.). The results obtained showed that durian had $56.1 \%$ moisture, $3.5 \%$ protein, $2.8 \%$ fat, $1.4 \%$ ash, $36.26 \%$ carbohydrate, $6.6 \%$ dietary fiber and $7.0 \mu \mathrm{g}$ of vitamin A. The mineral analysis results indicated that Durio dulcis is a good source of potassium, magnesium and phosphorus. Protein analysis found a total of sixteen major amino acids present in durian namely aspartame, serine, glutamin acid, glycine, histidine, arginine, threonine, alanine, proline, thyrosine, valine, methionine, lysine, isoleusine, leusine and phenylaline. A total of thirty-three individual fatty acids components were analysed. Among those, palmitic acid was a predominant saturated fatty acid while oleic acid was the most abundant unsaturated fatty acid. The composition of fatty acids showed that total of monounsaturated fatty acids, polyunsaturated fatty acids and saturated fatty acids were $56.7 \%, 6.7 \%$ and $36.6 \%$ respectively. A total of thirty-one volatile compounds were identified, among which alcohols, esters, sulphur-containing compounds and ketones were found to be the major constituents.
\end{abstract}

\section{Introduction}

While research efforts are concentrated in developing the better known local tropical fruits, very little work has been done on indigenous fruits which are found only in certain localised areas of Malaysia. Many of those fruits are unknown outside the areas where they are found. In Sabah, many interesting but lesser fruits have been reported (Noorfarahzilah et al., 2017; Jahurul, Ping, Sharifudin et al., 2019; Noorfarahzilah et al., 2020). Among these fruits, there are some species that possess the potential to be added to the list of promising tropical fruits in the country (Jahurul et al., 2018; Jahurul, Leykey, Rovina et al., 2019; Norazlina et al., 2020). Durio dulcis, locally known as 'durian merah', the fruits are small, green to orange in colour while the aril is red or orange and without the typical strong aroma under durian classes.

Durian (Durio zibethinus), a member of the Bombaceae family, is one of the most well-known tropical fruits in Southeast Asia, while Durio graveolens and Durio dulcis are the famous durians for people in Borneo Island and both of these durians are widely consumed by people in Sabah, Sarawak as well as
Brunei. However, despite the popularity of Durio zebethinus the over variety of durians could not be found in other places in Southeast Asia except in Borneo. These varieties of durian are important to local people and can only be found in a market as 'Tamu'. Traditionally, local people consumed it raw or preserved with salt before eaten. Although the tree of these durians is grown wild, the high demand for these varieties of durian is due to them believing that it has its medicinal effects and make this durian quite expensive compared to other types of durian.

The scientific findings of indigenous durian from Sabah are scarce. Most of the literature reported on the research conducted for Durio zibethinus (Lee-Hoon and Rajeev, 2015; Aziz and Jalil, 2019). Nasaruddin et al., (2013) reported the proximate and fatty acid compositions of yellow durian (Durio graveolens) obtained from Sabah, Malaysia. Due to limited information that has been reported with regards to Durio dulcis Becc., this study was conducted in order to determine the chemical and fatty acid composition of Sabah indigenous durian. 


\section{Materials and methods}

\subsection{Preparation of processed durian}

Durian fruits (Durio dulcis Becc) were obtained from a farm in Sipitang, Sabah, Malaysia (Figure 1). Ripened durian fruits that dropped naturally were collected and transported within $2 \mathrm{hrs}$ on the same morning (at $30 \pm 2^{\circ} \mathrm{C}$ ). Fruits were selected for uniformity of size and freedom of visual defects and were dehusked (the rind was cut open), by cutting along the suture on the back of the locules. Upon cutting, 4-6 separated fruit arils $(350-420 \mathrm{~g})$ were packed together. Care was taken not to break the epidermis of the pulp when removing it from the husk. The pulps were placed on polystyrene trays and wrapped in a commercially available lowdensity polyethylene (LDPE) cling film.

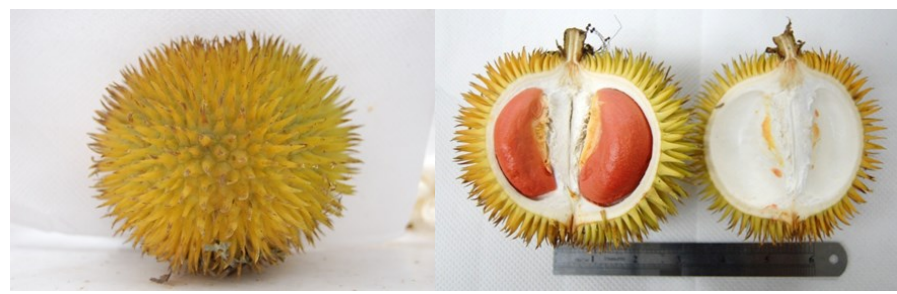

Figure 1. Durio dulcis morphology

2.2 Chemical composition and volatile compound analysis

The chemical composition and volatile compound analysis were carried out by an accredited commercial laboratory (Unipeq Sdn Bhd).

\subsubsection{Proximate composition and mineral analysis}

AOAC protocol (1995) was used to determine protein (981.10), fat (991.36), dietary fibre (991.43), moisture (950.46), ash (923.03) and vitamin A (960.45). Carbohydrate was determined by the difference method (Mamat et al., 2018). For mineral quantification, the elements of $\mathrm{Ca}, \mathrm{K}, \mathrm{Na}$ and $\mathrm{Mg}$ were measured by atomic absorption spectrophotometry (AAS) using a Varian Spectra atomic absorption spectrophotometer, model A400. Phosphorus was measured by Inductively coupled plasma mass spectrometry (ICP-MS).

\subsubsection{Fatty acid composition measurements}

To determine the fatty acid compositions, fat content was analysed using gas chromatography equipped with flame-ionisation detection (GC-FID) with fatty acids methyl ester standard. Gas chromatography analysis was conducted using an Agilent $6890 \mathrm{GC}$ with a flame ionisation detector (FID) (Agilent Technologies, USA) and a $30 \mathrm{~m} \times 0.32 \mathrm{~mm} \times 0.25 \mu \mathrm{m}$ film thickness Restek Famewax column. Typical run conditions were - injector temperature $250^{\circ} \mathrm{C}$, detector $275^{\circ} \mathrm{C}$, hydrogen carrier gas at $2.5 \mathrm{~mL} / \mathrm{min}$, a split ratio of 100:1, the make-up flow of
$45 \mathrm{~mL} / \mathrm{min}$. The initial oven temperature was $190^{\circ} \mathrm{C}$ held for $1 \mathrm{~min}$, then ramped at $5{ }^{\circ} \mathrm{C} / \mathrm{min}$ to reach the final temperature of $235^{\circ} \mathrm{C}$ and held for 2 mins.

\subsubsection{Amino acid determination}

The determination of amino acids was conducted by using HPLC-AccQ-Tag method.

\subsubsection{Volatile organic compound determination}

The composition of the volatile fraction of durian sample was investigated using a headspace sampling technique and gas chromatography coupled to mass spectrometry analysis (GC-MS).

\section{Results and discussion}

This study found that durian Durio dulcis consist of $56.1 \%$ moisture, $3.5 \%$ protein, $2.8 \%$ fat, $1.4 \%$ ash, $36.26 \%$ carbohydrate and $6.6 \%$ of dietary fibre (Table 1). The results show that this durian could provide a significant amount of protein and fat in our diet. The amount of protein, fat, ash and carbohydrate obtained were higher as compared to Durio zibethinus (Lim and Kamaruzzaman, 1990; Belgis et al., 2016) and Durio kutenjensis (Hoe and Siong, 1999). The differences between the results obtained might be due to cultivar, location of growth, climate, environmental conditions and soil type (Bishnoi and Khetarpaul, 1993). The environment of different locations plays an essential role in the determination of the nutritional composition of durian. The dietary fibre content of Durio dulcis was relatively higher (as compared to other fruits) where it's contributing $6.6 \mathrm{~g} / 100 \mathrm{~g}$ of the durian. Studies show that dietary fibre has demonstrated benefits for health maintenance and disease prevention where fibre is help for easy digestion, prevents constipation and bloating as while as contributing to colon health. Fibre may also play a role in regulating cholesterol levels and so helps to reduce the risk of heart disease (Marlett et al., 2002). This study also found that Durio dulcis contains a

Table 1. Chemical and mineral compositions of Durio dulcis

\begin{tabular}{lc}
\hline Parameter & Amount \\
\hline Protein, g/100 g & 3.5 \\
Fat, g/100 g & 2.8 \\
Carbohydrate, g/100 g & 36.2 \\
Ash, g/100 g & 1.4 \\
Moisture, g/100 g & 56.1 \\
Dietary fiber, g/100 g & 6.6 \\
Energy, kcal/100 g & $184(773 \mathrm{~kJ})$ \\
Calcium, $\mathrm{mg} / 100 \mathrm{~g}$ & 181.2 \\
Potassium, $\mathrm{mg} / 100 \mathrm{~g}$ & 4358.6 \\
Magnesium, $\mathrm{mg} / 100 \mathrm{~g}$ & 413.1 \\
Sodium, $\mathrm{mg} / 100 \mathrm{~g}$ & 67.3 \\
Phosphorus, $\mathrm{mg} / 100 \mathrm{~g}$ & 326.9 \\
\hline
\end{tabular}


significant amount of vitamin A $(7.0 \mathrm{mg} / 100 \mathrm{~g})$. Vitamin $\mathrm{A}$ is an important macronutrient because it plays essential roles in vision, growth, and development; the development and maintenance of healthy skin, hair, and mucous membranes; immune functions; and reproduction.

Mineral analysis results found that Durio dulcis is a good source of potassium and magnesium where the amount of these elements was 4358.60 and 413.10 $\mathrm{mg} / 100 \mathrm{~g}$, respectively. Dietary potassium intake is reported to have antihypertensive effects, prevents strokes, and improves cardiovascular outcomes (Penton et al., 2015). Magnesium plays a vital function in several essential cellular processes such as intermediary metabolism, DNA replication and repair, transporting potassium and calcium ions, cell proliferation together with signalling transduction (Blaszczyk and DudaChodak, 2013). Moreover, this variety of durian also provided phosphorus, calcium and sodium $(329.9,181.2$ and $67.3 \mathrm{mg} / 100 \mathrm{~g}$, respectively). The trend of the results obtained in this investigation is in agreement with the findings reported by Charoenkiatkul et al. (2016). In general, the composition of minerals in durians are influenced predominantly by the soil in which the plants are cultivated.

Amino acids are essential precursors for the production of hormones and low-molecular weight nitrogenous components, with each having extensive biological importance (Wu, 2009). Table 2 lists the amount (grams per $100 \mathrm{~g}$ ) of sixteen amino acids determined in this present study. The acid amino profile revealed that the primary amino acids in the aril of durian were valine $(0.459 \mathrm{~g} / 100 \mathrm{~g})$, alanine $(0.447 \mathrm{~g} / 100$ $\mathrm{g})$, glutamic acid $(0.348 \mathrm{~g} / 100 \mathrm{~g})$, proline $(0.333 \mathrm{~g} / 100$ $\mathrm{g})$, leucine $(0.249 \mathrm{~g} / 100 \mathrm{~g})$ and lysine $(0.224 \mathrm{~g} / 100 \mathrm{~g})$. All of the essential amino acids were detected in the durian sample except tryptophan. These essential amino acids accounted for approximately $41 \%$ of the total amino acid composition of the durian sample. $\mathrm{Wu}(2009)$ defined essential amino acid as either those amino acids whose carbon skeletons cannot be synthesised or those that are inadequately synthesised de novo by the body relative to needs and which must be obtained from the diet to achieve sufficient requirements. These amino acids play a substantial role in numerous processes, including energy metabolism, enhancing the immune function, tissue development, as well as nutrient absorption (Wu, 2010). The quality of proteins depends mainly on their amino acid concentration, especially their composition of essential amino acids. Other amino acids also present but with little amount. The presence of several amino acids such as alanine, proline, phenylalanine and isoleucine could contribute to the bitter taste of durian (Belgis et al., 2016). Amino acids are contributed to fruit flavours, by acting as precursors of volatile compounds involved in fruit aromas (Tieman et al., 2006). Several volatile compounds are produced by the action of enzyme systems on amino acids when the tissue of the vegetable is damaged (Christensen et al., 2007).

\begin{tabular}{lc}
\multicolumn{2}{l}{ Table 2. Amino acid profiles of Durio dulcis } \\
\hline Amino Acid & Amount $(\% \mathrm{w} / \mathrm{w})$ \\
\hline Essential & \\
\hline Histidine & 0.017 \\
Threonine & 0.117 \\
Valine & 0.459 \\
Methionine & 0.073 \\
Lysine & 0.224 \\
Isoleucine & 0.112 \\
Leucine & 0.249 \\
Phenylalanine & 0.119 \\
\hline Non-essential & \\
\hline Serine & 0.155 \\
Glycine & 0.133 \\
Aspartic acid & 0.311 \\
Arginine & 0.153 \\
Glutamic acid & 0.348 \\
Alanine & 0.447 \\
Proline & 0.333 \\
Tyrosine & 0.107 \\
\hline
\end{tabular}

Fatty acids are important as a source of energy source and membrane constituents. They have biological activities that act to regulate cell and tissue metabolism, function, and responsiveness to hormonal and other signals (Calder, 2015). Fatty acid composition analysis of durian found a total of thirty-three individual fatty acid components in extracted fat. Among those, palmitic acid (C16:0) was a predominant saturated fatty acid $(31.0 \%)$ while oleic acid (C18:1) was the most abundant monounsaturated fatty acid $(52.6 \%)$. Palmitic acid is the major fatty acid occurring naturally in animals and vegetables as well as is the main component of human milk fats. Other fatty acids were also identified as $\alpha$ linolenic $(\mathrm{C} 18: 3 \mathrm{n} 3)$, cis-linolenic $(\mathrm{C} 18: 2 \mathrm{n} 6 \mathrm{c})$, translinolelaidic (C18:2n6t), palmitoleic (C16:1), pentadecanoic (C15:0) and myristic acids (C14:0), where their amount was less than $2 \%$ respectively. The composition of fatty acids showed that a total of monounsaturated fatty acids, polyunsaturated fatty acids and saturated fatty acids were $55.61 \%, 7.28 \%$ and $37.06 \%$ respectively (Table 3 ). The relationship between saturated and polyunsaturated fatty acid content is expressed as $\mathrm{P} / \mathrm{S}$ index. This value is an important parameter for the determination of the nutritional value of particular oil. Oils and fats with a higher value of $\mathrm{P} / \mathrm{S}$ index than 1 are considered to have nutritional value (Kostik et al., 2013). The value of $\mathrm{P} / \mathrm{S}$ index for the durian sample was 1.25. A study by Phutdhawong et al., 
Table 3. Classification of saturated fatty acids, unsaturated fatty acids, and omega in methyl ester of Durio dulcis

\begin{tabular}{|c|c|c|c|}
\hline Structure & Fatty acid methyl ester & $\%$ of fat extracted & Classification* \\
\hline $\mathrm{C} 8: 0$ & Caprylic & 0.04 & SFA \\
\hline $\mathrm{C} 10: 0$ & Capric & 0.1 & SFA \\
\hline $\mathrm{C} 11: 0$ & Undecanoic & 0.38 & SFA \\
\hline $\mathrm{C} 12: 0$ & Lauric & 0.58 & SFA \\
\hline $\mathrm{C} 13: 0$ & Tridecanoic & 0.15 & SFA \\
\hline $\mathrm{C} 14: 0$ & Myristic & 0.88 & SFA \\
\hline C14:1 & Myristoleic & 0.28 & MUFA \\
\hline $\mathrm{C} 15: 0$ & Pentadaecanoic & 0.32 & SFA \\
\hline C15:1 & Cis-10- Pentadaecanoic & 0.26 & MUFA \\
\hline $\mathrm{C} 16: 0$ & Palmitic & 31.02 & SFA \\
\hline C16:1 & Palmitoleic & 1.68 & MUFA \\
\hline $\mathrm{C} 17: 0$ & Heptadecanoic & 0.06 & SFA \\
\hline C17:1 & Cis-10- Heptadecanoic & 0.18 & MUFA \\
\hline $\mathrm{C} 18: 0$ & Stearic & 1.27 & SFA \\
\hline C18:1n9c & Oleic & 52.55 & Omega 9 \\
\hline $\mathrm{C} 18: 2 \mathrm{n} 6 \mathrm{t}$ & Linolelaidic (Trans) & 1.38 & Omega 6 \\
\hline $\mathrm{C} 18: 2 \mathrm{n} 6 \mathrm{c}$ & Linoleic (Cis) & 2.55 & Omega 6 \\
\hline C18:3n6 & $\gamma$-Linoleic & 0.06 & Omega 6 \\
\hline $\mathrm{C} 18: 3 \mathrm{n} 3$ & $\alpha$-Linoleic & 0.39 & Omega 3 \\
\hline C20:0 & Arachidic & 1.65 & SFA \\
\hline $\mathrm{C} 20: \ln 9$ & Cis-11-Eicosenic & 0.07 & Omega 9 \\
\hline C20:2 & Cis-11,14-Eicosadienoic & 0.07 & Omega 6 \\
\hline $\mathrm{C} 20: 3 \mathrm{n} 6$ & Cis-8,11,14- Eicosatrienoic & 0.9 & Omega 6 \\
\hline $\mathrm{C} 20: 3 \mathrm{n} 3$ & Cis-11,14,17-Eicosatrienoic & 0.17 & Omega 3 \\
\hline $\mathrm{C} 20: 4 \mathrm{n} 6$ & Arachidonic & 0.1 & Omega 6 \\
\hline $\mathrm{C} 20: 5 \mathrm{n} 3$ & Cis-5,8,11,14,17-ecosapentaenoic & 0.12 & Omega 3 \\
\hline $\mathrm{C} 21: 0$ & Henicosanoic & 0.41 & SFA \\
\hline $\mathrm{C} 22: \ln 9$ & Erucic & 0.59 & Omega 9 \\
\hline $\mathrm{C} 22: 2$ & Cis-13,16-Docosadienoic & 1.31 & Omega 6 \\
\hline $\mathrm{C} 22: 6 \mathrm{n} 3$ & Cis-4,7,10,13,16,19-Docosahexaenoic & 0.13 & Omega 3 \\
\hline $\mathrm{C} 23: 0$ & Tricosanoic & 0.16 & SFA \\
\hline $\mathrm{C} 24: 0$ & Lignoceric & 0.04 & SFA \\
\hline $\mathrm{C} 24: \ln 9$ & Nervonic & 0.1 & Omega 3 \\
\hline
\end{tabular}

*SFA - Saturated fatty acid, MUFA - Monounsaturated fatty acid

(2015) on Thai durian aril found a high amount of stearic acid (C18:0). In contrast, Durio dulcis contains a high amount of oleic acid and palmitic acid, and low amount of stearic acid. Replacement of dietary saturated fat by oleic acid and/or polyunsaturated fatty acids (PUFA) has been elucidated to decrease the cardiovascular risk by lowering blood lipids, mainly cholesterol (LopezHuertas, 2010). A significant amount of essential fatty acids was also detected in the Durio dulcis. According to Kaur et al. (2014), the term essential fatty acids (EFA) refers to those polyunsaturated fatty acids (PUFA) that must be provided by foods because these cannot be manufactured in the body yet are necessary for health. There are two categories of EFA, omega- $3(\omega-3)$ and omega-6 ( $\omega-6)$. Omega-3 fatty acids have a final carboncarbon double bond in the $\omega-3$ position, i.e. the third bond from the methyl end of the fatty acid whereas $\omega-6$ fatty acids have it in the $\omega-6$ position, i.e. the sixth bond from the methyl end of the fatty acid. The total percentage of essential fatty acids in durian is $5.84 \%$. Among the main EFAs detected were cis-9,12- octadecadienoic acid (18:2 (n-6)), cis-13,16docosadienoic acid (22:2 (n-6)) and cis-8,11,14eicosatrienoic (20:3 (n-6)). The roles of EFA in human health is described comprehensively by Glick and Fischer (2013).

The organic volatile compound analysis found that Durio dulcis variety is rich in volatiles alcohols, esters, sulphur compounds and ketones (Table 4) that contribute to unique flavour and taste of durian. There are thirtyone volatile compounds determined in this present work. The main volatile component of alcohol was 2-methyl-1propanol, 3-methyl-1-butanol, and 2,4-dimethyl-3pentanol. Another alcohol compound detected was 2methyl-1-butanol and 2,6-dimethyl-4-heptanol. Esters are the second most predominant volatile compound in durian after alcohol. The major ester compounds in the sample were detected as propanoic acid, 2-methyl-, 2methylbutyl ester, propanoic acid, 2-methyl-, 3methybutyl ester and propanoic acid, 2-methyl, methyl ester. Besides alcohol and ester, sulfur is another primary 
Table 4. The volatile compound of durian measured by GC-MS headspace

\begin{tabular}{|c|c|c|c|c|c|}
\hline Peak No & Retention & Area $(\%)$ & Name of compound & CAS No. & Functional \\
\hline 1 & 1.461 & 2.2 & Ethanethiol & $75-08-1$ & $\mathrm{SCC}$ \\
\hline 2 & 2.056 & 24.7 & 2-methyl-1-propanol & $78-83-1$ & Alcohol \\
\hline 3 & 2.296 & 0.6 & 3-methyl-butanal & $590-86-3$ & Aldehyde \\
\hline 4 & 2.536 & 6.57 & Methyl thiourea & $598-52-7$ & SCC \\
\hline 5 & 2.679 & 0.37 & 2-methyl-, methyl ester propanoic acid & $547-63-7$ & Ester \\
\hline 6 & 3.269 & 0.41 & $\begin{array}{l}\text { Methyl (methyl-4-deoxy-2-0-methyl. beta. 1-threo-hex-4- } \\
\text { enolpyranosid) uronate }\end{array}$ & $52425-23-0$ & Ester \\
\hline 7 & 3.463 & 13.09 & 3-methyl-1-butanol, & $123-51-3$ & Alcohol \\
\hline 8 & 3.538 & 2.22 & 2-methyl-1-butanol, & $137-32-1$ & Alcohol \\
\hline 9 & 3.921 & 2.6 & 2-methyl-, ethyl ester propanoic acid & $97-62-1$ & Ester \\
\hline 10 & 4.184 & 0.13 & Isobutyl acetate & $110-19-0$ & Ester \\
\hline 11 & 4.247 & 0.97 & 1-chloro-1-butanethiol, 3-methyl-penatane & $541-31-1$ & $\mathrm{SCC}$ \\
\hline 12 & 4.653 & 0.11 & 4-Propoxy-2-butanone & $89975-71-3$ & Ketone \\
\hline 13 & 5.529 & 0.16 & 3-methyl-ethyl ester butanoic acid & $108-64-5$ & Ester \\
\hline 14 & 5.609 & 8.86 & 2,4-dimethyl-3-pentanol & $600-36-2$ & Alcohol \\
\hline 15 & 5.895 & 0.09 & 3-methyl-, acetate-1-butanol & $123-92-2$ & Ester \\
\hline 16 & 6.444 & 19.16 & 2-methyl-, butyl ester propanoic acid & $97-87-0$ & Ester \\
\hline 17 & 6.553 & 0.26 & Diethyl disulfide & 110-81-6 & SCC \\
\hline 18 & 6.862 & 0.36 & Hexyl isobutyl carbonate & $959067-98-2$ & Ketone \\
\hline 19 & 6.931 & 0.58 & 2,6-dimethyl-4-heptanol, & $108-82-7$ & Alcohol \\
\hline 20 & 7.022 & 0.15 & $\begin{array}{c}\text { 2-methyl-, 2,2-dimethyl-1-(2-hydroxy-1-methylethyl) propyl ester } \\
\text { propanoic acid }\end{array}$ & $74367-33-2$ & Ester \\
\hline 21 & 7.589 & 0.06 & Ethyl ester hexanoic acid & $123-66-0$ & Ester \\
\hline 22 & 7.64 & 0.16 & Butyl 2-methybutanoate & $15706-73-7$ & Ester \\
\hline 23 & 7.675 & 0.26 & Isobutyl isovalerate & $589-59-3$ & Ester \\
\hline 24 & 7.755 & 3.56 & 2-methyl-, 3-methybuyl ester propanoic acid & $3 / 1 / 2050$ & Ester \\
\hline 25 & 7.801 & 0.14 & 2-methyl-, 2-methybuyl ester propanoic acid & $2445-69-4$ & Ester \\
\hline 26 & 8.453 & 0.07 & Ethyl 1-methypropyl disulfide, & $54166-53-9$ & $\mathrm{SCC}$ \\
\hline 27 & 8.842 & 0.06 & Pentyl ester pentanoic acid, & $2173-56-0$ & Ester \\
\hline 28 & 9.328 & 0.15 & 2-methylpropyl ester hexanoic acid & $105-79-3$ & Ester \\
\hline 29 & 9.809 & 0.12 & Ethyl ester octanoic acid, & $106-32-1$ & Ester \\
\hline 30 & 11.257 & 0.2 & n-Caprylic acid isobutyl ester & $3 / 6 / 5461$ & Ester \\
\hline 31 & 12.962 & 0.08 & n-Capric acid isobutyl ester & $673-38-2$ & Ester \\
\hline
\end{tabular}

*SCC - Sulphur containing compound

compound in durian. A total of five sulphur compounds identified as methyl thiourea, ethanethiol, 3methylbutane-1-thiol, diethyl disulfide and ethyl 1methypropyl disulfide. Sulphur-containing components were generally contributing for the distinct onion and rubber odour in durian fruit. Two ketones (4-propoxy-2butanone and hexyl isobutyl carbonate) and one aldehyde (3-methyl butanal) compounds were also identified. The total volatile compounds identified for Durio dulcis was lower than reported by earlier published findings. Chin et al. (2007) investigated volatile compounds from Malaysian durians (Durio zibethinus). A total of 39 volatile compounds were identified including 22 esters, 9 sulphur-containing alkanes, 3 thioacetals, 2 thioesters, 2 thiolanes and 1 alcohol. Jaswir et al. (2005) reported a total of 38 durian volatile compounds compromising mostly esters and acids in durian aril (variety D24).

\section{Conclusion}

In conclusion, these findings showed that indigenous durian could provide a significant amount of nutrients for human. Durio dulcis provides about $62 \%$ of unsaturated fatty acid as well as $184 \mathrm{kcal} / 100 \mathrm{~g}$ energy. Protein analysis showed that both essential and non-essential amino acids were presented. Information presented can be used by nutritionists and food technologists to improve the nutrition of local people and develop food products that would be beneficial to human health.

\section{Conflict of interest}

The authors declare no conflicts of interest.

\section{Acknowledgements}

The authors acknowledge financial support from Malaysia Higher Learning Education, ERGS grant 
(ERGS0003-STWN-1/2011), FRG0289-STWN-2/2010 and the facilities provided and supported by the Faculty of Food Science and Nutrition, Universiti Malaysia Sabah (UMS) for the study.

\section{References}

AOAC. (1995). Official Method of Analysis of the Association of Official Analytical Chemists, 16th ed., Washington D.C.: AOAC.

Aziz, N.A.A. and Jalil, A.B.M.H. (2019). Bioactive compounds, nutritional value, and potential health benefits of indigenous durian (Durio zibethinus Murr.): A review. Foods, 8(3), 96. https:// doi.org/10.3390/foods8030096

Belgis, M., Wijaya, C.H., Apriyantono, A., Kusbiantoro, B. and Yuliana, N.D. (2016). Physicochemical differences and sensory profiling of six lai (Durio kutejensis) and four durian (Durio zibethinus) cultivars indigenous Indonesia. International Food Research Journal, 23(4), 1466-1473.

Bishnoi, S. and Khetarpaul, N. (1993). Effect of domestic processing and cooking methods on invitro starch digestibility of different pea cultivars (Pisum sativum). Food Chemistry, 47(2), 177-182. https://doi.org/10.1016/0308-8146(93)90240-G

Blaszczyk, U. and Duda-Chodak. A. (2013). Magnesium: its role in nutrition and carcinogenesis. Roczniki Państwowego Zaktadu Higieny, 64(3), 16571.

Calder, P.C. (2015). Functional roles of fatty acids and their effects on human health. Journal of Parenteral and Enteral Nutrition, 39(Suppl. 1), 18S-32S. https://doi.org/10.1177/0148607115595980

Charoenkiatkul, S., Thiyajai, P. and Judprasong, K. (2016). Nutrients and bioactive compounds in popular and indigenous durian (Durio zibethinus murr.). Food Chemistry, 193, 181-186. https:// doi.org/10.1016/j.foodchem.2015.02.107

Chin, S.T., Nazimah, S.A.H., Quek, S.Y., Man, Y.B.C., Rahman, R.A. and Hashim, D.M. (2007). Analysis of volatile compounds from Malaysian durians (Durio zibethinus) using headspace SPME coupled to fast GC-MS. Journal of Food Composition Analysis, 20, 31-44. https://doi.org/10.1016/ j.jfca.2006.04.011

Christensen, L.P., Edelenbos, M. and Kreutzmann, S. (2007). Fruits and Vegetables of Moderate Climate. In Berger, R.G (Ed.). Flavours and Fragrances Chemistry, Bioprocessing and Sustainability. p. 135188. New York: Springer Berlin Heidelberg. https:// doi.org/10.1007/978-3-540-49339-6_7

Glick, N.R. and Fischer, M.H. (2013). The role of essential fatty acids in human health. Journal of Evidence-Based Complementary and Alternative Medicine, 18(4), 268-289. https:// doi.org/10.1177/2156587213488788

Lee-Hoon, H. and Rajeev, B. (2015). Exploring the potential nutraceutical values of durian (Durio zibethinus L.) - An exotic tropical fruit. Food Chemistry, 168(1), 80-89. https://doi.org/10.1016/ j.foodchem.2014.07.020

Hoe, V.B. and Siong, K.H. (1999). The nutritional value of indigenous fruit and vegetables in Sarawak. Asia Pacific Journal of Clinical Nutrition, 8(1), 24-31. https://doi.org/10.1046/j.1440-6047.1999.00046.x

Jahurul, M.H.A., Soon, Y., Sharifudin, M.S., Hasmadi, M., Mansoor, A.H., Zaidul, I.S.M., Lee, J.S., Zzaman, W. and Jinap, S. (2018). Bambangan (Mangifera pajang) kernel fat: A potential new source of cocoa butter alternative. International Journal of Food Science and Technology, 53(7), 1689-1697. https://doi.org/10.1111/ijfs. 13753

Jahurul M.H.A, Ping L.L, Sharifudin M.S., Hasmadi M., Mansoor A.H., Lee J.S., Amir H.M.S., Jinap S. and Zaidul, I.S.M. (2019). Thermal properties of bambangan (Mangifera pajang) kernel fat and palm stearin blends as cocoa butter alternatives. LWT Food Science and Technology, 107, 64-71. https:// doi.org/10.1016/j.lwt.2019.02.053

Jahurul, M.H.A., Leykey, B., Rovina, K., Shafiquzzaman, S., Sharifudin, M.S., Hasmadi, M., Mansoor, A.H., Jinap S. and Zaidul, I.S.M. (2019). Valuable components of bambangan fruit (Mangifera pajang) and its co-products: A review. Food Research International, 115, 105-115. https:// doi.org/10.1016/j.foodres.2018.08.017

Jaswir, I., Che Man, Y.B., Selamat, J., Ahmad, F. and Sugisawa, H. (2005). Effect of processing conditions and storage on retention of volatile components of durian leather. Journal of Food Agriculture and Environment, 3, 66-72.

Kaur, N., Chugh, V. and Gupta, A.K. (2014). Essential fatty acids as functional components of foods- a review. Journal of Food Science and Technology, 51, 2289-2303. https://doi.org/10.1007/s13197-0120677-0

Kostik, V., Memeti, S. and Bauer, B. (2013). Fatty acid composition of edible oils and fats. Journal of Hygienic Engineering and Design, 4, 112-116.

Lim, T.K. and Kamaruzzaman S. (1990). Penyakit Tanaman Durian. Malaysia: Dewan Bahasa dan Pustaka, Kementerian Pendidikan Malaysia.

Lopez-Huertas, E. (2010). Health effects of oleic acid and long chain omega-3 fatty acids (EPA and DHA) 
enriched milks. A review of intervention studies. Pharmacological Research, 61(3), 200-207. https:// doi.org/10.1016/j.phrs.2009.10.007

Mamat, H, Akanda, J. M H., Zainol, M.K. and Yu, A.L. (2018). The influence of seaweed composite flour on the quality of muffin. Journal of Aquatic Food Product Technology, 27(5), 635-642. https:// doi.org/10.1080/10498850.2018.1468841

Marlett, J.A., McBurney, M.I. and Slavin, J.L. (2002). Position of the American Dietetic Association: Health implications of dietary fiber. Journal of American Diet Association, 102(7), 993-1000. https://doi.org/10.1016/S0002-8223(02)90228-2

Nasaruddin, M.H., Mohd Noor, N.Q.I and Mamat, H. (2013). Komposisi proksimat dan komponen asid lemak durian kuning (Durio graveolens) Sabah. Sains Malaysiana, 42(9), 1283-1288.

Norazlina, M.R., Jahurul, M.H.A., Hasmadi, M., Sharifudin, M.S., Patricia, M., Mansoor, A.H. and Jau-Shya, L. (2020). Characteristics of bambangan kernel fat fractions produced by solvent fractionation and their potential industrial applications. Journal of Food Processing and Preservation, e14446. https:// doi.org/10.1111/jfpp.14446

Noorfarahzilah, M, Mansoor, A.H. and Mamat, H. (2017). Proximate composition, mineral content and functional properties of tarap (Artocarpus odoratissimus) seed flour. Food Research, 1(30), 8996. https://doi.org/10.26656/fr.2017.3.025

Noorfarahzilah, M., Jau-Shya, L., Mansoor, A.H., Jahurul, M.H.A., Umi Hartina, M.R., Zainol, M.K. and Hasmadi, M. (2020). Physicochemical properties of tarap (Artocarpus adoratisimus) starch. Food Research, 4(3), 602-611. https://doi.org/10.26656/ fr.2017.4(3).337

Penton, D., Czogalla, J. and Loffing, J. (2015). Dietary potassium and the renal control of salt balance and blood pressure. Pflügers Archiv - European Journal of Physiology, 467, 513-530. https:// doi.org/10.1007/s00424-014-1673-1

Phutdhawong, W., Kaewkong, S. and Buddhasukh, D. (2005). GC-MS analysis of fatty acids in Thai durian aril. Chiang Mai Journal of Science, 32(2), 155-158.

Tieman, D., Taylor, M., Schauer, N., Fernie, A.R., Hanson, A.D. and Klee, H.J. (2006). Tomato aromatic amino acid decarboxylases participate in synthesis of the flavor volatiles 2-phenylethanol and 2-phenylacetaldehyde. Proceedings of the National Academy of Sciences of the United States of America, 103, 8287-8292. https://doi.org/10.1073/ pnas. 0602469103

Wu, G. (2009). Amino acids: metabolism, functions, and nutrition. Amino Acids, 37, 1-17. https:// doi.org/10.1007/s00726-009-0269-0

Wu, G. (2010). Functional Amino Acids in Growth, Reproduction, and Health. Advances in Nutrition, 1 (1), 31-37. https://doi.org/10.3945/an.110.1008 